\title{
LAS FOTOGRAFÍAS DE CALIFORNIA DE RAFAEL CASTRO Y ORDÓÑEZ, MIEMBRO DE LA EXPEDICIÓN CIENTÍFICA DEL PACÍFICO (1862-1866): DISCURSO Y CIRCULACIÓN
}

\author{
Sara Badia-Villaseca \\ Programa de Doctorado en Historia e Historia del Arte y del Territorio, Escuela de Doctorado, Facultad de Geografía e Historia \\ Universidad Nacional de Educación a Distancia (UNED) \\ sarabadiav@yahoo.es
}

Recibido: 24 febrero 2016; Aceptado: 13 julio de 2016.

Cómo citar este artículo/Citation: Badia-Villaseca, Sara (2016), "Las fotografías de California de Rafael Castro y Ordóñez, miembro de la Expedición Científica del Pacífico (1862-1866): discurso y circulación", Asclepio, 68 (2): p153. doi: http://dx.doi.org/10.3989/ asclepio.2016.25

RESUMEN: En octubre de 1863 Rafael Castro y Ordóñez, artista y fotógrafo de la Comisión Cientíica del Pacífico, viajó junto al naturalista Francisco de Paula Martínez y Sáez por el estado de California. La Comisión acompañaba una expedición militar y política de corte panhispanista. Fruto de aquel viaje el artista produjo una veintena de fotografías, dibujos y varias cartas que se publicarían en la revista El Museo Universal. Fotografías y crónicas del viaje conforman un corpus de excepcional valor que permite reconstruir el proyecto y su fabricación de una nueva imagen de América tras la independencia de las antiguas colonias y la irrupción de los Estados Unidos como potencia emergente. Este trabajo analiza este discurso y cómo se articuló con relación a este recién incorporado territorio de los Estados Unidos. A lo largo del estudio se revelarán varios fenómenos interesantes, como la ruptura ocasional del discurso, la circulación de las fotografías más allá del contexto de la Expedición o las conexiones de este viaje de exploración con el fenómeno del turismo.

PALABRAS CLAVE: Fotografía; Expediciones; Literatura de viajes; California; Siglo XIX.

\section{RAFAEL CASTRO, PHOTOGRAPHER AND CHRONICLER OF THE “EXPEDICIÓN CIENTÍFICA DEL PACÍFICO” (1862-1866) AND HIS VISION OF CALIFORNIA}

ABSTRACT: In October 1863, Rafael Castro y Ordóñez, artist and photographer of the Comisión Científica del Pacífico, traveled across the State of California in the company of naturalist Francisco de Paula Martínez y Sáez. The Comisión was associated with a panHispanic military and political expedition. As a result of the expedition the artist produced around twenty photographs, drawings, and several letters that were ultimately published by the Spanish pictorial magazine El Museo Universal. Both his photographs and travel accounts make up an exceptionally valuable body of knowledge allowing to reconstruct not only the Comisión project but also its attempt at portraying a new image of America following the independence of Spain's former colonies and the ascent of the United States as a world power. This paper analyzes both this discourse and its expression in relation to California, a then recently incorporated US territory. Several interesting phenomena, including occasional breaches in the discourse, the circulation of photographs beyond the expedition's context, and the connections of this exploration journey with tourism, will be unveiled in the course of the present study.

KEYWORDS: Photography; Expeditions; Travel Literature; Illustrated Press; California; 1800s.

Copyright: ( 2016 CSIC. Este es un artículo de acceso abierto distribuido bajo los términos de la licencia Creative Commons Attribution (CC BY) España 3.0. 
Tras varios meses de travesía por América del Sur, en octubre de 1863 varios de los componentes de la Comisión Científica del Pacífico llegaron a California. La Comisión formaba parte de la Expedición del Pacífico (Barreiro, 1926; Miller, 1968; Puig-Samper, 1988), una ambiciosa embajada del gobierno de la Unión Liberal liderada por Leopoldo O'Donnell creada en el marco de una política exterior intervencionista, bien dirigida a obtener un prestigio perdido, como ha querido ver la historiografía tradicional, bien con claros objetivos económicos (Martínez Gallego, 2001, pp. 156-164; Inarejos, 2007, pp. 9, 103-104). En cualquier caso, bajo la ideología del panhispanismo (Van Aken, 1959; Puig-Samper y López-Ocón, 1987; Puig-Samper, 1991) la empresa tendría por objetivo la negociación de la deuda peruana, y la «protección a los españoles [y la] fraternización con todos los hispano-americanos ${ }^{1}$ aunque concluiría con la Guerra del Pacífico, lo que quizá ilustra una actitud vacilante en lo que respecta a la aceptación de las independencias como hecho irreversible (Pérez Viejo, 2012a, p. 123).

El Ministerio de Fomento organizó con cierta premura una comisión científica que habría de acompañar a la Expedición (Puig-Samper, 1988, p. 12). El proyecto tenía como objetivo reanudar la tradición científica ilustrada en la que se inspiraba (Puig-Samper, 1988, p. 19). La decisión de contar para dicha organización con Mariano de la Paz y Graells, director del Museo Nacional de Ciencias Naturales (Puig-Samper, 1988, p. 15), que años antes había participado en la presentación del daguerrotipo en Madrid (Fontanella, 1981, pp. 39-42), debió influir en la incorporación de un fotógrafo al proyecto, lo que contribuía al prestigio de la Expedición (Badia-Villaseca, López-Ocón, PérezMontes, 2000, p. 129). Las expediciones científicas oficiales continuaban utilizando artistas viajeros, principalmente dibujantes. La Comisión también contaba, bajo la dirección del marino retirado y coleccionista Patricio María Paz y Membiela, con los naturalistas Marcos Jiménez de la Espada, Francisco de Paula Martínez y Sáez, Fernando Amor y Mayor, Juan Isern Batlló, el antropólogo Manuel Almagro y el médico auxiliar disecador Bartolomé Puig y Galup. La Comisión, que en varias ocasiones se dividiría con el objetivo de maximizar su rendimiento, tendría la oportunidad de viajar por Brasil, Uruguay, Argentina, Islas Malvinas, Chile, Perú, Ecuador, Panamá y California. California aparecía entre los puertos a visitar desde los inicios del proyecto, según las instrucciones recibidas por Hernández Pinzón, y también allí la escuadra debía actuar como una embajada de buena voluntad que contribuyera al buen nombre de España tras la indepen- dencia (Miller, 1968, p. 95). Rafael Castro, de regreso a Madrid, visitó también Nueva York, de la que dejó un interesante testimonio. Con todo, la Expedición del Pacífico tuvo lugar en un momento de intensa crisis política (Burdiel, 2011, pp. 692-786) que con los años desembocaría en el destronamiento de Isabel II y que sin duda debió afectar los destinos del proyecto.

Rafael Castro realizó en California cerca de una veintena de negativos al colodión húmedo centrándose en el bosque de secuoyas gigantes de Calaveras, las minas de oro de Murphy's, y los emigrantes chinos de San Francisco así como, de manera muy fragmentada, algunos rincones de esta ciudad (Puig-Samper, 1992). Como en otros puntos del periplo, se adquirió además un pequeño conjunto de fotografías con el que se completó la colección de vistas urbanas. El fotógrafo ejercía también como cronista en El Museo Universal (Puig-Samper, 1988, p. 69), donde publicó el más extenso repertorio de literatura de viaje de esta popular revista ilustrada (Chozas, 2014, p. 106). La revista reproducía sus fotografías (y algunos de sus dibujos) (Páez Ríos, 1952, pp. 43-45) en forma de grabados en madera intercalados en los textos.

\section{RAFAEL CASTRO, ARTISTA DE LA EXPEDICIÓN CIENTÍ- FICA DEL PACÍFICO}

Desde el siglo XVIII los artistas eran considerados «el alma del viaje, pues representarán en vivo aquellas cosas que en vano aún la pluma más diestra se esforzaría de describir ${ }^{2}$. Si bien es cierto que algunas de las imágenes de Castro fueron claramente concebidas como documentos científicos ${ }^{3}$,la mayoría de sus fotografías estaba posiblemente dirigida a documentar los lugares visitados conforme se hacía en las narrativas de las expediciones que se publicaban desde los tiempos de Cook, "... so that we might go out with every help that could serve to make the result of our voyage entertaining to the generality of readers, as well as instructive to the sailor and scholar...» ${ }^{4}$. Durante el siglo XIX el destino de las imágenes continuó siendo la narrativa, documentar los lugares visitados y los acontecimientos más señalados de los viajes, aunque en ocasiones tuvieron vocación científica. Pero, nunca inocentes, las imágenes suelen presentar una lectura ideológica.

Podría argumentarse que estas fotografías no ilustraron la narrativa de Manuel Almagro ${ }^{5}$, posiblemente debido a motivos económicos ${ }^{6}$. Pero la correspondencia que se conserva nos permite comprender la función que originalmente se les destinaba. Mientras para el director del Museo de Ciencias Naturales las fotografías estaban destinadas a circular entre «las 
corporaciones, altos funcionarios, literatos y hombres científicos» siendo posible «vender a los particulares que gusten adquirirlas» ${ }^{7}$, para el ministro Vega de Armijo su función debía ser «ilustrar la historia del viaje ${ }^{8}$. Finalmente el destino de estas fotografías fue la formación de veinte álbumes ${ }^{9}$ cuya existencia ha sido imposible corroborar, lo que se procuró a lo largo de varios años en medio de grandes dificultades ${ }^{10}$. Todo apunta a que las imágenes fueron celosamente custodiadas por el Ministerio, donde se pierde su rastro: en 1879 la Asociación Española de Historia Natural le reclamaba las colecciones completas de fotografías con «vistas, vegetación, cráneos, e indígenas» con destino a las bibliotecas del Jardín Botánico y del Museo de Ciencias Naturales para así satisfacer los gustos de sus lectores ${ }^{11}$. Junto con algunos dibujos ${ }^{12}$, un número reducido de fotografías ${ }^{13}$ formó parte de la exposición que se celebró en el Jardín Botánico en 1866 que, según la prensa de la época, fue todo un éxito (Puig-Samper, 1988, p. 339). Además, las cartas y grabados publicados por El Museo Universal prestaron extraoficialmente al proyecto una visibilidad extraordinaria. Y la circulación de las imágenes habría sido aún más amplia de no haberse privado al fotógrafo de sus derechos de propiedad a su regreso a Madrid ${ }^{14}$. Es necesario observar que si bien no se ha encontrado ningún acuerdo contractual que confirme los derechos defendidos por el fotógrafo, es posible que Castro se amparara en la ley de 1847 por la que un autor/artista (y sus descendientes por un plazo de tiempo) ostentaba poder total de disponer de su producción (Sánchez García, 2002, pp. 1000, 1002). Sin embargo, los derechos con relación a las fotografías eran un asunto controvertido y sin legislar por aquellos años. Del mismo modo, aunque se trata sólo de una hipótesis, esta ley podría explicar qué fue de los dibujos que también realizó. Por otra parte, es necesario recordar que las imágenes de las expediciones tradicionalmente pertenecían a sus organizadores aunque se producen entonces reivindicaciones similares, como la de la familia de Joseph Selleny, artista de la expedición de la fragata Novara, a la Marina austríaca (Donko, 2011, p. 72).

Imágenes y palabras se complementan ofreciendo un corpus fotográfico contextualizado de enorme valor histórico que articula un complejo discurso con gran proyección en la sociedad española de la época. La colección destaca además por su cronología, ámbito geográfico, dimensiones o temática así como por su relación con una expedición militar y científica y con un periodismo gráfico incipiente. Permite reconstruir un complejo discurso que, procedente de un ámbito científico y oficial, debió ser considerado digno de todo crédito y tener una importante proyección en la sociedad española. Por un lado, imágenes y palabras permitieron re-conocer unas tierras americanas que, aunque ya no pertenecían a la corona, eran todavía consideradas importantes, particularmente desde la óptica del panhispanismo. Pero hay más. La apasionada personalidad de este artista, que acabaría pegándose un tiro en el corazón en diciembre de 1865 , produjo fracturas en este discurso. Como embajador de la expedición, Castro ponía en valor el trabajo realizado por los comisionados y auguraba el éxito del proyecto, al tiempo que veía y enseñaba a ver a través de los ojos del panhispanismo que no sólo animaba la empresa expedicionaria sino los intereses de la prensa para la que también trabajaba. Sin embargo, su agitada personalidad le conduciría en numerosas ocasiones a exponer sus propias ideas.

Rafael Eduardo Casto Castro y Ordóñez (Madrid, 1834-1865) ${ }^{15}$ fue elegido comisionado pocos días antes de la partida de la Expedición tras la renuncia de su primer candidato (Puig-Samper, 1988, p. 69). Hijo del pintor Antonio Castro y Gistau $^{16}$, se había formado en la Real Academia de Bellas Artes de San Fernando de Madrid y disfrutó de una pensión que le permitió completar su formación con Léon Coignet (Ossorio y Bernard, 1868, p. 151), afamado pintor y prestigioso maestro, en París. Éste posiblemente le inculcara su interés por la fotografía dada su relación con Société Héliographique, centrada en explorar las capacidades del nuevo medio como expresión artística. Destacó en las exposiciones nacionales de 1858 y 1860 (Ossorio y Bernard, 1868, p. 151). Posiblemente debido al prestigio de la mención honorífica obtenida en la última (Pantorba, 1980, pp. 75-76) obtuvo el encargo oficial de un retrato de la serie cronológica de los Reyes de España (Ossorio y Bernard, p.151) en la que participaron figuras de renombre. Su carrera resulta característica de la época pues refleja cómo «el pintor español del siglo XIX pinta... por y para el Estado» (Pérez Viejo, 2012b, p. 38), principal mecenas. Además de ejercer como pintor en Madrid, tal y como se dedujo por primera vez a partir de un retrato de la familia de Isern, tenía también un estudio especializado en retratos fotográficos en formato carte de visite (Blanco, Rodríguez y Rodríguez, 2006, p. 684). De hecho, muchos pintores de la época, acuciados por la necesidad de obtener ingresos regulares, optaron por adoptar la fotografía como profesión. Quizá lo más interesante de esta faceta sea su Galería de los Contemporáneos (imprenta E. Aguado: Madrid, 1862), una serie de retratos de hombres ilustres acompañadas 
de reseñas biográficas de J. de la Viña ${ }^{17}$. La serie, que se adquiría en forma de entregas y por suscripción ${ }^{18}$, gozaba de cierta circulación conforme al reverso de una carte de visite de Emilio Castelar de la Fundación Lázaro Galdiano por la que sabemos que también se vendía en la Librería de A. Duran (Yeves, 2011, p. 252). Es interesante observar que la serie presenta grandes similitudes con Galerie des contemporains de A. A. E. Disdéri, creador del formato carte de visite y uno de los fotógrafos comerciales más importantes de la época. Así, aunque como fotógrafo demuestra una clara vocación comercial, ambición e iniciativa, su interés por este producto también demuestra cierto prestigio y familiaridad con los más importantes personajes de la época que, sin duda, debieron granjearle el camino a la Expedición. Más aún, la concepción del arte como discurso ideológico propia de los artistas de aquellos años (Pérez Viejo, 2012b, p. 46) se ve reflejada en toda su trayectoria y explica su papel en el contexto expedicionario. Aunque con sólidos conocimientos, el fotógrafo británico Charles Clifford, cuya obra constituye un hito en la Historia de la Fotografía en España (Fontanella, 1981, p. 61), recibió el encargo oficial de adquirir y probar parte de su equipo, instruyéndole también en vistas (Puig-Samper, 1988, p. 24). Sin duda el interés de Rafael Castro por la Expedición constituye un reflejo más de su sintonía con los intereses del Estado y, a juzgar por el éxito de la fotografía de viaje en aquella época ${ }^{19}$, de sus esperanzas de añadir un producto comercial más a su negocio.

\section{CALIFORNIA}

Una serie de trágicos acontecimientos conferiría a este viaje un carácter de tragedia romántica (Puig-Samper, 2011, p. 38). En Chile, el fotógrafo ya había relegado su cámara a un segundo plano y parecía absorto en su labor para El Museo Universal, aflorando en sus textos impresiones personales que sugieren un estado de ánimo alterado. A su llegada a California parece experimentar angustia $^{20}$, agotamiento psíquico ${ }^{21}$, desilusión ante la evolución del proyecto ${ }^{22}$ y un fuerte impacto emocional por la muerte de varios militares ${ }^{23} y$ de Fernando Amor. Castro, que junto a otros compañeros le había velado y acompañado, le rinde homenaje como «mártir de la ciencia» con una fotografía del hospital donde murió que sería publicada por El Museo Universal (imagen 1$)^{24}$.

El viaje refleja su estado de ánimo y constituye una experiencia privilegiada para hallar la verdad sobre los lugares que visita pero también sobre su propio país. Afirma en una de sus crónicas: «... Largo fuera de enumerar tantos adelantos (...) necesitamos convencer-
Imagen 1. [Federico] Ruiz (dibujo), [Bernardo] Rico (grabado), Rafael Castro y Ordóñez (fotografía), Expedición Científica al Pacífico- Casa de Salud, San Francisco de California. 1863-1864, grabado en madera. CCSIC, CCHS, Biblioteca Tomás Navarro Tomás, Madrid. Sig. RESP/055C. El Museo Universal, 31 de enero de 1864, p. 36, [en línea], disponible en: http://www.cervantesvirtual.com/nd/ ark:/59851/bmcht3b7 [consultado el 27/1/2016].
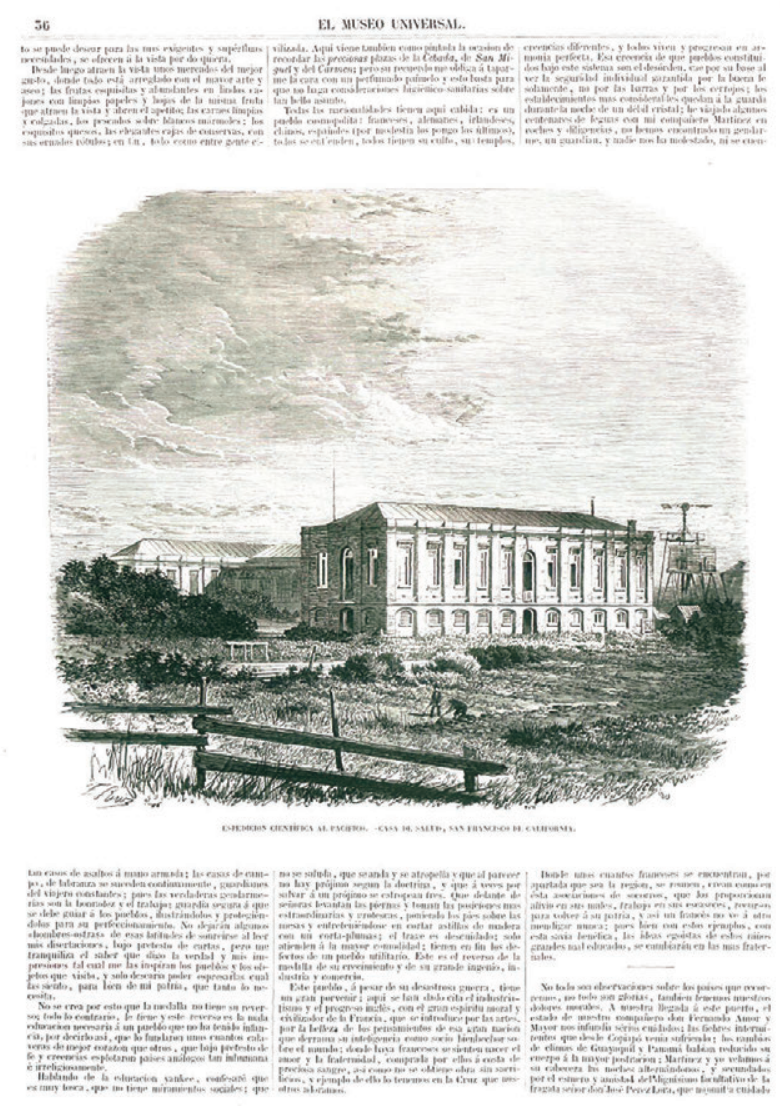

nos de que si fuimos, hoy no somos nada... $\nu^{25}$. A partir de aquí utiliza su descripción del progreso de California para ilustrar el declive de España aunque, en varias ocasiones, su discurso sirve para sugerir mejoras con vistas a una posible «regeneración ${ }^{26}$. Estos «niños grandes maleducados» que son los Estados Unidos, "pueblo que no ha tenido infancia» aparecerán en sus crónicas como modelo para la formación de compañías de bomberos, modernización de mercados ${ }^{27} 0$ de la vida doméstica ${ }^{28}$, modelo en fin de civilización y progreso. Aunque en España no se siente progreso, algunos individuos habían visto el mal y buscaban una fórmula que arrastrara a todo el pueblo al ritmo de los países europeos, movimiento en el que jugará un importante papel Emilio Castelar (Boneu Farre, 1962, pp. 106-107), a quien Rafael Castro incluyó en la pri- 
mera entrega de su Galería, lo que sugiere quizá cierta admiración. Los viajes románticos españoles permiten a sus autores fijar la mirada en la modernidad y la civilización de otros países más desarrollados. Y en esta búsqueda existe una inspiración para la regeneración de España (Díaz Larios, 2002, p.95).

La próspera civilización norteamericana, descrita como un lugar donde «... se ha dado cita el industrialismo inglés con el gran espíritu moral y civilizador de la Francia...», es relacionada por el fotógrafo con su colonización, lo que le sirve para criticar el modelo hispano ${ }^{29}$. Sin duda, un discurso excepcional en el contexto español que no debió de ser del gusto de los editores de El Museo Universal, con una marcada línea nacionalista (Chozas, 2014, p.109), ni con los propósitos del gobierno, de los que nos da idea la prensa de la época:

... Todo indica ya el no lejano establecimiento de una vasta confederación hispano-americana bajo el protectorado de la España, libre y espontáneamente aceptada (...) Esta gran verdad encierra en sí el germen de la salvación y de la prosperidad para las repúblicas hispanoamericanas. La expedición naval se encamina ya a la realización de esa grande obra moral y política... ${ }^{30}$.

Casi desde la independencia de los Estados Unidos, que España había apoyado, se observa un marcado antiamericanismo basado en la desconfianza hacia el nuevo modelo socio-político y en el ascenso de un poderoso rival, que habría de fraguarse a lo largo del siglo XIX en torno al discurso panhispanista (Fernández de Miguel, 2012, p. 27, 30).

\section{SECUOYAS Y MINAS DE ORO}

A pesar de la gravedad de su compañero Fernando Amor, Castro y Martínez y Sáez se dirigieron al interior del estado de California, según el fotógrafo con el principal objetivo de visitar el bosque de Secuoya gigantea $^{31}$. Tal y como ocurre a lo largo de toda la Expedición, el trabajo de los comisionados dependía en gran medida de la ayuda de diplomáticos, residentes españoles, coleccionistas y hombres de ciencia. En esta ocasión este colaborador fue Edward Vischer, hombre de negocios alemán afincado en aquellas tierras que, alcanzada la madurez, se había interesado en la creación y edición de libros ilustrados sobre California (Puig-Samper, 2011, p. 28). Vischer contaba con amplios conocimientos sobre la zona a la que había dedicado un volumen ${ }^{32}$. El diario original de Martínez y Sáez conserva el itinerario de viaje, trazado por el alemán (Puig-Samper, 1988, pp. 248-249) ${ }^{33}$.
El reportaje sobre el bosque de secuoyas fluctúa entre la fotografía de interés botánico y la reproducción de una experiencia turística pre fabricada lo que, en parte, viene provocado por la probable lectura de la obra de Vischer.

Los negativos $^{34}$ ACN000/008/120y ACN000/008/122 son en realidad imágenes de ejemplares de $\mathrm{Se}$ quoia gigantea y Pinus lambertiana y Abies amabilis. No existen diferencias entre estas fotografías y otras láminas botánicas del siglo XIX, y como tal funciona ACN000/008/122 (imagen 2), sin acreditar, en Vischer's Views of California (San Francisco, después de 1863$)^{35}$. Las fotografías del tronco de la secuoya talada Original Big Tree ACN000/008/128, ACN000/008/125 y ACN000/008/117 también denotan interés por estos ejemplares como especímenes botánicos. La imagen ACN000/008/128, también utilizada por Vischer (imagen 3), responde al interés por las dimensiones colosales de estos árboles, particularmente evidente gracias a la figura humana que les sirve de escala. Los numerosos anillos entre los que son visibles algunos marcadores históricos sugieren la antigüedad de estos especímenes.

Imagen 2. Rafael Castro y Ordóñez, Los Centinelas, Big Tree, California [Pinus lambertiana y Abies amabilis]. 1863, copia en papel albuminado sobre cartón, $26,2 \mathrm{x}$ 21,0 cm. Colección del Museo Nacional de Antropología, Madrid. Sig. FD1388. Fotografía: Miguel Ángel Otero.

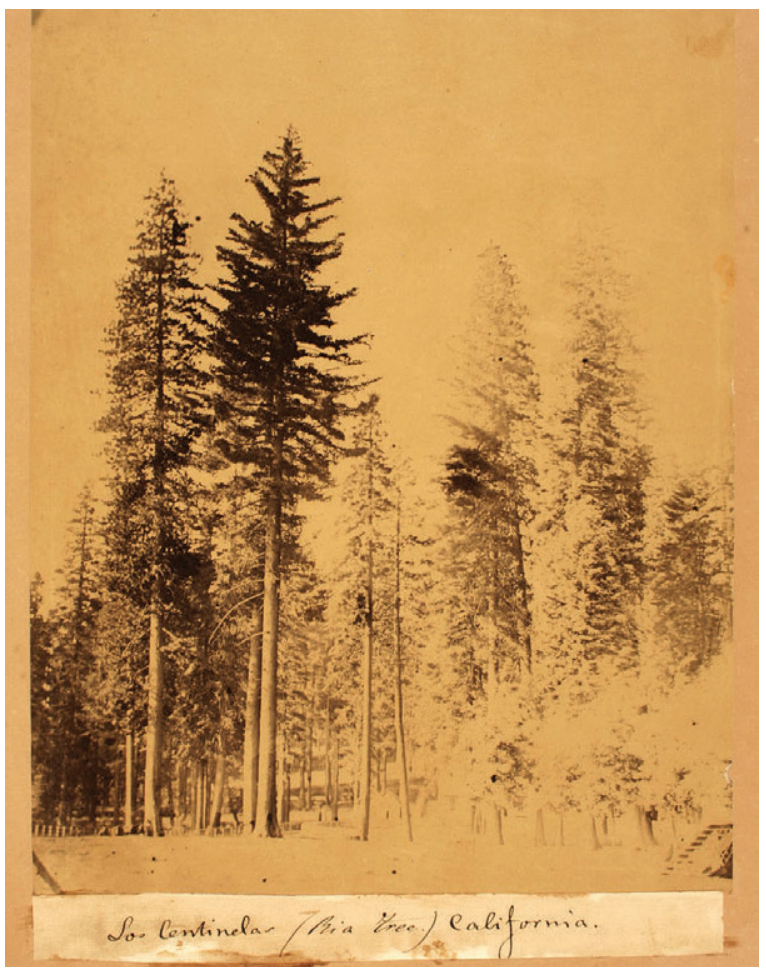


Imagen 3. [Rafael Castro y Ordóñez], Log of the Original Big Tree. 1863, reproducción. Yale Collection of Western Americana, Beinecke Rare Book and Manuscript Library. Sig. Zc72+864x. Edward Vischer (1864), The Forest Trees of California, San Francisco.

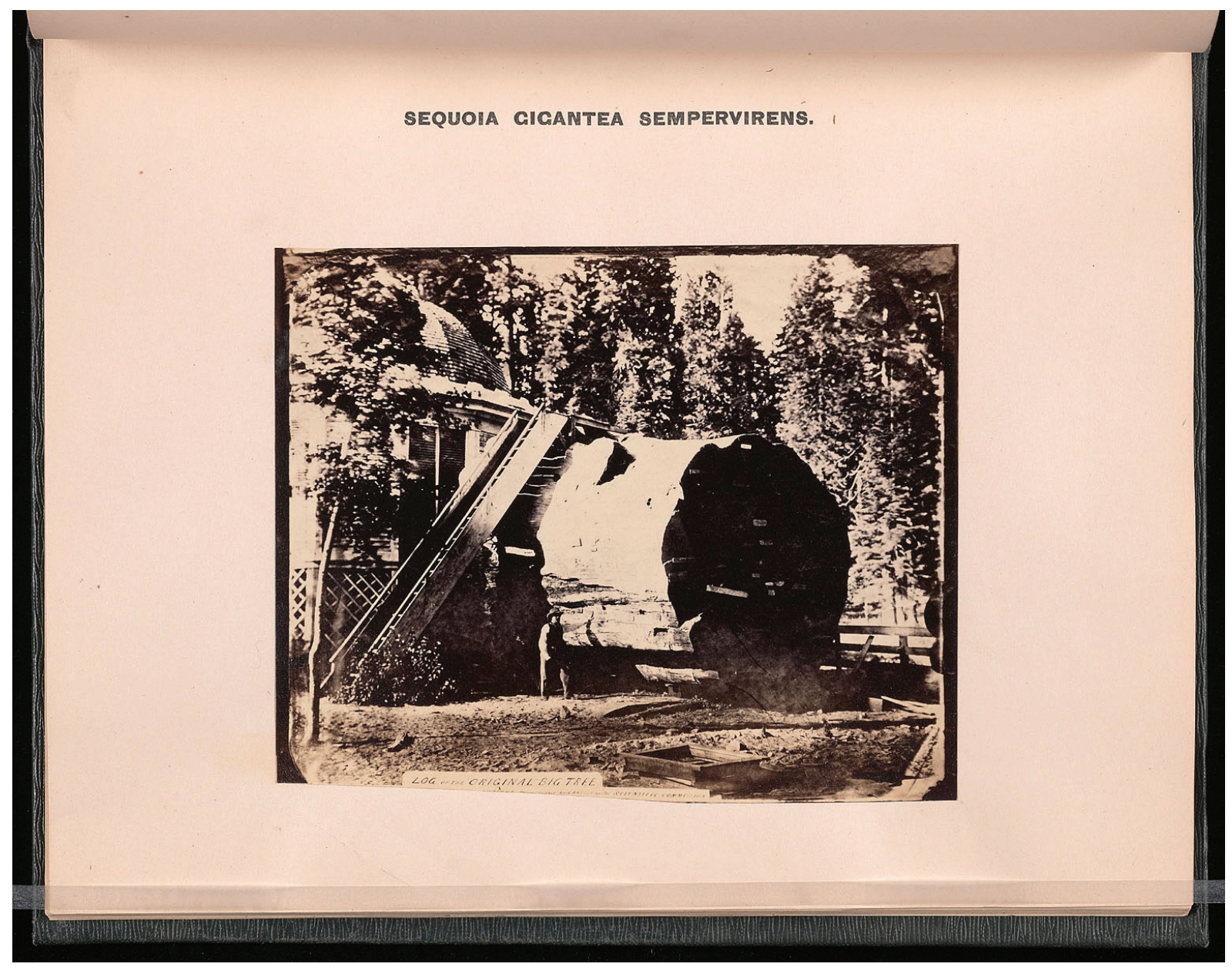

Pero estas imágenes también describen una atracción turística. El pabellón visible en ACN000/008/128 cubría la parte inferior del árbol y servía como pista de baile en las fiestas que allí se celebraban. Ésta y ACN000/008/125 comparten la presencia de una escalera, un importante hito de la visita según se deprende de las numerosas imágenes con turistas que se conservan. La imagen permite ver además los grafiti que múltiples turistas habían dejado en el tronco del árbol como testigo de su paso. ACN000/008/117 expone el "cadáver vandalizado» de la copa, utilizada en una cervecería y bolera, aquí ya desmanteladas ${ }^{36}$. Las imágenes del árbol son complementadas por las de las instalaciones hoteleras ACN000/008/129 y ACN000/008/123, comentadas positivamente por el fotógrafo.

Las imágenes apuntan por igual a un interés científico y a la recepción y reproducción de una experien- cia pre fabricada, fenómeno similar al del Grand Tour (Sweet, 2012, p. 21). La visita a este árbol talado, junto al hotel para turistas, aparece reflejada poco tiempo después en las cartas de William H. Brewer, miembro de la California Geological Survey ${ }^{37}$. Esto vendría a demostrar el interés de la exhibición de este ejemplar talado y diseccionado para el conocimiento de estos especímenes botánicos y el de estos destinos turísticos para la sociedad de la época. Parte de una tradición, la experiencia de la visita con sus distintos hitos aparece ya fijada en las primeras guías a estos parajes. Una atenta mirada a las ilustraciones de Views of California: The Mammoth Tree Grove, Calaveras County, California, and its Avenues (San Francisco, 1862) de Vischer, revela los mismos motivos y puntos de vista, que serían utilizados por Castro en sus fotografías (imagen 4). 
Imagen 4. Edward Vischer (dibujo)? 10.- Stump and Log of the Original Big Tree, 1855, from Photographs; 11.The Father of the Forest. Antes de 1862, reproducción. Missouri Botanical Garden. Edward Vischer (1862), Views of California: The Mammoth Tree Grove, Calaveras County, California, and its Avenues, San Francisco, p. VII, [en línea], disponible en: http://www.archive.org/details/mobot31753002794649 [consultado el 27/1/2016].

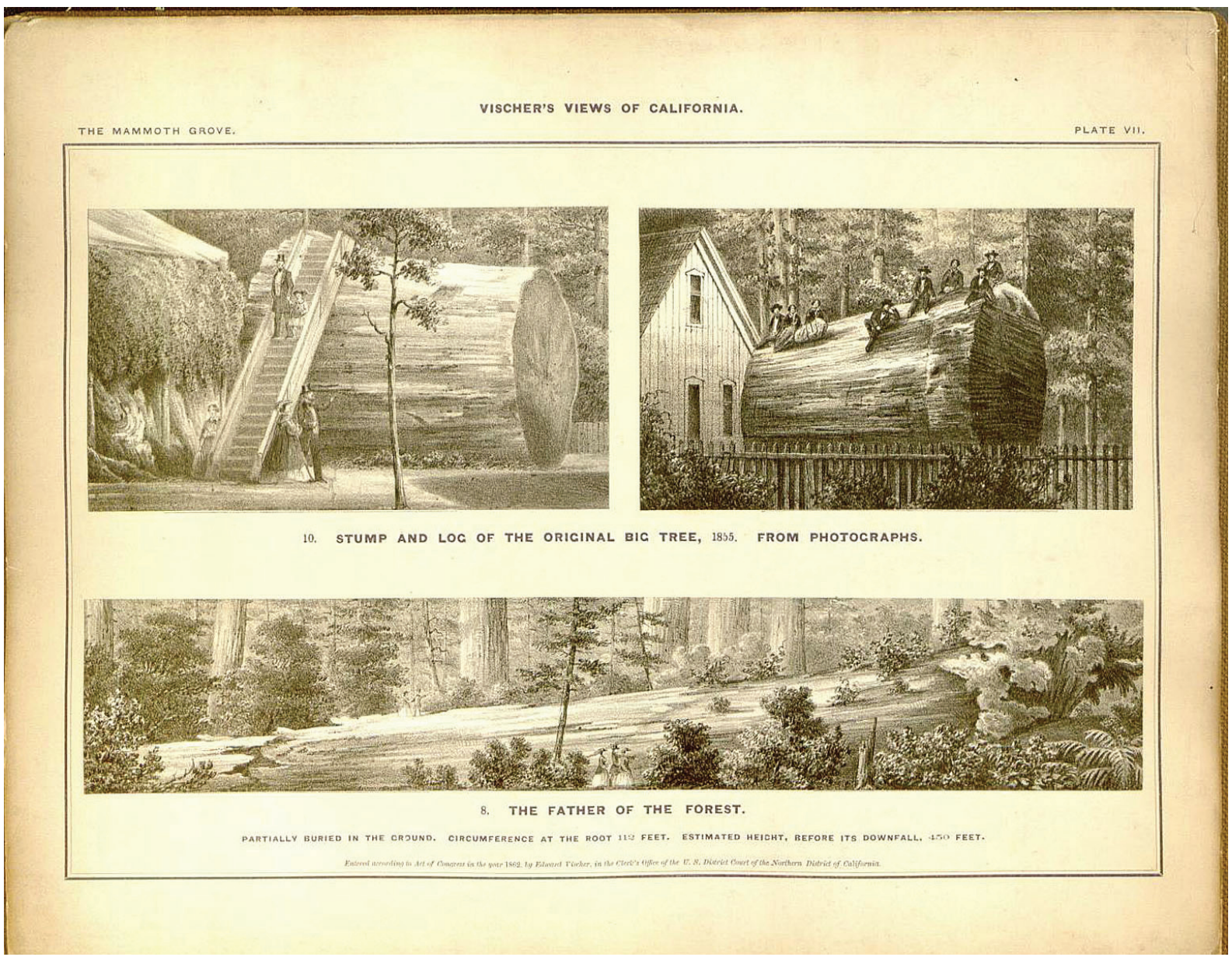

Más aún, las fotografías del artista de la Comisión llegarán a sustituir estos dibujos. Y así, por ejemplo, Log of the Original Big Tree, que se corresponde con el negativo ACN000/008/128 ya comentado, viene a sustituir al dibujo Stump and Log of the Original Big Tree en The Forest Trees of California (San Francisco, 1864) (imagen 3). La comprensión del bosque como un lugar para el descanso de la sociedad local tampoco difiere de la perspectiva de Vischer. Y, de la misma manera, se repiten incluso las sensaciones entre los diferentes visitantes ${ }^{38}$. Con todo el fotógrafo, siempre interesado en dar credibilidad a su discurso, expresa su admiración pero se aleja de cualquier alusión a lo sublime $^{39}$ para describir estos maravillosos árboles a través de un lenguaje objetivo ${ }^{40}$.

La publicación de Vischer de 1862 esconde otro secreto, un hecho inadvertido para Peter E. Palmquist que posiblemente desconocía las publicaciones de Castro en El Museo Universal. Sus dibujos The Three Graces y Mother and Son muestran asombrosas coincidencias con los grabados Expedición al Pacífico, árboles gigantes, grupo de Las Tres Gracias y Expedición al Pacífico.- Árboles gigantes, La Madre y El Hijo publicados por El Museo Universal ${ }^{41}$. Claramente inspirados en los anteriores, como las descripciones de los árboles expresados en pies ingleses, coinciden con la publicación del alemán. Por tanto, parece más que probable que las imágenes e información textual de Castro estuvieran basadas en Views of California (San Francisco, 1862) de Vischer, y que a su vez contribuyeran a difundir una tradición visual.

Este circuito de maravillas naturales debe considerarse también un lugar emblemático de la cultura americana. La relación creada entre divinidad, natu- 
raleza y nación permitía a los parques naturales servir como símbolos, auténticos lugares de culto para el pueblo americano. Así, estos árboles milenarios, eslabones con el pasado más lejano ${ }^{42}$, sin duda fueron rápidamente asociados a la idea de «monumentos naturales» con los que competir con los de civilizaciones más antiguas, y quizá por ello recibieron con el tiempo nombres de personajes emblemáticos de la cultura americana que debían perpetuarse (Hutchinson, 2004 , pp. 54, 57). Por tanto, tales lugares fueron esencialmente considerados instituciones museológicas, no sólo en sus contenidos sino en sus técnicas de exposición (Patin, 1999, p. 41), tal y como parece demostrar el diseccionado Original Big Tree. Más allá del simple destino turístico, constituían un medio para definir los Estados Unidos (Sears, 1989, p. 5).

Los comisionados omitieron cualquier comentario con relación a la tala, mutilación y explotación de los árboles. Como ocurriera con el Original Big Tree, muchos árboles fueron descortezados o talados $y$, reducidos así a "monstruos de feria», fueron exhibidos por todo el mundo. «... To our mind it seems a cruel idea, a perfect desecration, to cut down such a splendid tree (...) to... be exhibited (...) In Europe such a natural production would have been cherished and protected, if necessary by law...", afirma la revista ilustrada Gleason's Pictorial en $1853^{43}$. Diez años después la prensa española se hacía eco del riesgo de desaparición de estos árboles ${ }^{44}$. Y, de hecho, el bosque de secuoyas de Mariposa Grove consiguió, junto a Yosemite, protección legal a partir de 1864 aunque no así los Calaveras Big Trees que visitaron los comisionados, que continuaron siendo un destino turístico (Sears, 1989, p. 146). Teniendo en cuenta la sensibilidad de la sociedad decimonónica ante la posible desaparición de etnias, monumentos o tradiciones debido a la irrupción del progreso, el silencio de los expedicionarios resulta llamativo. El reiterativo motivo de los árboles talados en el arte norteamericano, que ha recibido atención por parte de los historiadores del arte, ha sido identificado con la conquista de la naturaleza salvaje y el avance del progreso de la civilización estadounidense (Novak, 1980, pp. 157-202 y Cikovski, 1979, pp. 611-626). Así, árboles talados y diseccionados, incluso reducidos a atracciones de feria, parecen expresar en las fotografías de Castro una aceptación de la domesticación de la naturaleza inherente al imparable avance del progreso norteamericano. Un progreso que sería celebrado por los propios norteamericanos pocos años después a través de imágenes de leñadores, árboles mutilados y turistas (Vermaas, 2003, pp. 116, 164).
De la misma manera, las imágenes de las minas de oro de la vecina localidad de Murphy's permiten al fotógrafo expresar una vez más la imparable fuerza del progreso. Evidentemente, la mineralogía y la explotación minera eran temas de interés para la Expedición. Sin embargo, la narrativa del viaje escrita por Manuel Almagro descubre en estas minas un tema de trascendencia histórica. La extraordinaria riqueza minera del estado, comenta, no fue explotada por España o por México sino por Estados Unidos al adueñarse de aquel territorio ${ }^{45}$. Las minas, que eran uno de los principales motores del progreso norteamericano, recordaban a los españoles su aparente incapacidad a la hora de explotar sus antiguos dominios o, en palabras de Vischer, que el nuevo elemento anglosajón era el causante de «... the new stir of life and activity infused into hitherto torpid and dormant arteries... ${ }^{46}$.

Murphy's había surgido en las proximidades de los placeres descubiertos por los hermanos Daniel y John Murphy, pioneros asentados en California en 1844 que realizarían prospecciones durante la Fiebre del Oro con enorme éxito. El fotógrafo de la Comisión, con el tiempo contado, realizó a primera hora de la mañana y en compañía de su compañero Martínez y Sáez y su colaborador Francisco Laso de la Vega dos fotografías de las minas, correspondientes a los negativos ACN000/008/127 y ACN000/008/126 (imagen 5). Las imágenes se centran en los ingenios utilizados y en la gestión del agua, aspectos importantes de la explotación que llamaron la atención de ambos comisionados. Estas imágenes, una vista panorámica y otra más centrada en una noria de agua, fueron enormemente populares, tal y como demuestra su presencia en todas las colecciones, su publicación en forma de grabado ${ }^{47}$ y su múltiple aparición en el mundo editorial norteamericano a lo largo de varios años ${ }^{48}$.

La insistencia sobre el motivo de la rueda, que ocupa un lugar central en ambas composiciones, merece cierta atención. La rueda surge en medio de una tierra quebrantada y abierta que evoca una imagen de destrucción. Entre otros significados, la rueda es conocida como símbolo de progreso, idea que parece utilizar el propio Castro cuando afirma:

... esto es un gran país, lleno de vida, de movimiento. iY todavía había hombre en esa que creía que sólo íbamos a encontrar indios en estos pueblos! ¡Pobres majaderos que niegan que el mundo marcha como su símbolo, que son el vapor y la electricidad! Que no se paren, que marchen, si no la rueda los destrozará... ${ }^{49}$. 
Imagen 5. Rafael Castro y Ordóñez, [Placeres, minas de oro]. 1863, copia en papel albuminado a partir de negativo al colodión húmedo, 20,0 x 27,0 cm. CCSIC, CCHS, Biblioteca Tomás Navarro Tomás, Madrid. Sig. ABGH000/117/351.

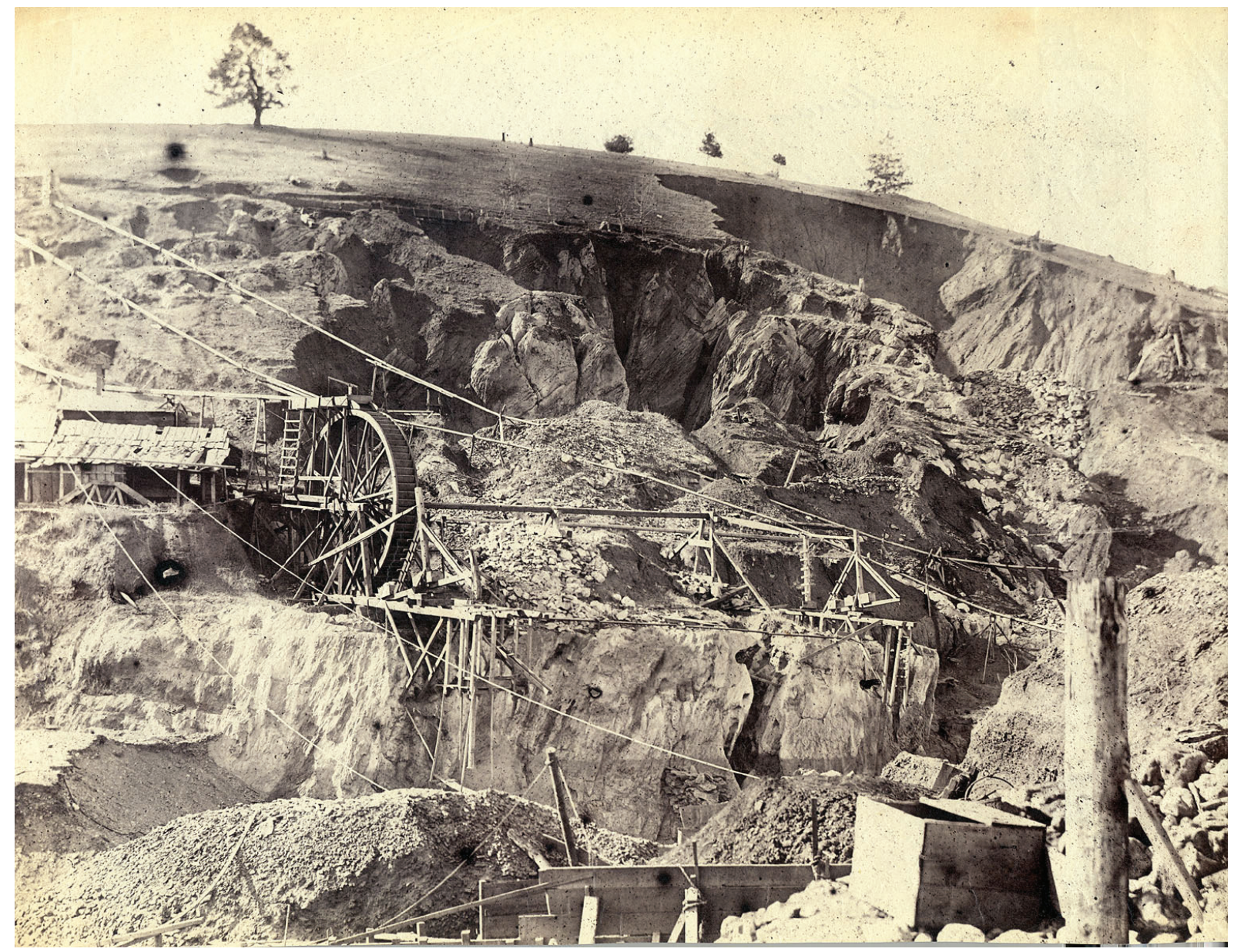

Vischer había utilizado las minas de Murphy's para destacar la belleza y sublimidad del vecino bosque de secuoyas. En Views of California (San Francisco, 1862) afirma que las minas constituyen "... waste and destruction in every form... bearing mute testimony to the demoniac power of Mammon... $\nu^{50}$. En otras palabras, para el alemán las minas eran lugares de destrucción que simbolizaban el materialismo y la avaricia. El fotógrafo también alude al progreso de California con relación al materialismo, y afirma: «... Este crecimiento, esta abundancia y este movimiento industrial y comercial (...) un tal desarrollo es debido en parte a la ambición y codicia de nuestra pobre humanidad... $\nu^{51}$. Una vez más las obras de Vischer y Castro muestran cierta afinidad. El progreso entrañaba una ocupación del espacio, una explotación de los recursos naturales y una destrucción que, en este caso, el fotógrafo parece presentar a través de una cierta visión apocalíptica y quizá moralizante.

\section{LAS «OTRAS VIDAS» DE LAS IMÁGENES}

Estas imágenes demuestran el impacto del trabajo de los expedicionarios españoles en la periferia (López-Ocón, Badia-Villaseca, 2003, p. 516). Las fotografías realizadas por Castro durante su periplo por el interior de California circularon a través de las publicaciones de Vischer, en cuya obra a su vez el fotógrafo español claramente se inspiró. Y, a su vez, las publicaciones de Vischer contribuyeron a la popularización de las obras del fotógrafo de la Comisión del Pacífico en los Estados Unidos. Así, una de sus fotografías de las minas de oro de Murphy's pasó a ilustrar la edición de cartas de William H. Brewer, miembro de la California Geological Survey. La reuti- 
lización de las imágenes destinadas a documentar los lugares visitados parece un fenómeno que se repite, al menos con relación a la Expedición Malaspina.

Peter E. Palmquist identificó las fotografías de Castro en dos publicaciones de Vischer: [The Forest Trees of California:] Sequoia Gigantea, Calaveras Mammoth Tree Grove (San Francisco, 1864) y Pictorial of California (San Francisco, 1870) (Palmquist, 1982, pp. 15-19). Se ha observado que se reprodujo al menos otra imagen, aunque sin acreditar, en Vischer's Views of California, the Mammoth Tree Grove, Calaveras County, California and its Avenues (San Francisco, después de 1863) (ejemplar de la Honnold Mudd Library). No se pueden descartar otros posibles préstamos debido a la enorme disparidad en las ediciones del alemán. Las imágenes de Castro que fueron publicadas por Vischer en Estados Unidos posiblemente no estaban protegidas por los derechos de copyright, que en aquellos años se negaba a las obras de origen europeo (Khan, 2008, pp. 26-27), pero en su mayoría aparecen debidamente acreditadas al fotógrafo y a la Comisión. No se trata de un hecho excepcional pues Vischer se relacionaba con artistas, como el fotógrafo Carleton E. Watkins o el paisajista de origen británico Thomas Hill, a los que pedía imágenes para reproducir en sus publicaciones y acreditaba su trabajo (Vermaas, 2003, p. 70).

A su vez, Castro no sólo se inspiró en la obra de Vischer, particularmente Views of California (San Francisco, 1862), sino que se basó en dos de sus dibujos para uno de sus proyectos de El Museo Universal. No se trata de un fenómeno aislado ya que las colecciones del Pacífico conservan múltiples imágenes de fotógrafos locales observándose la formación de un corpus de imágenes americanas paralelo que complementa el trabajo del fotógrafo de la Comisión. Como en el caso de los dibujos de Vischer, algunas de las imágenes de este corpus fue publicado por El Museo Universal sin la debida acreditación. La ley de 1847 establecía que el derecho de reproducción de la obra plástica se asignaba no a su autor sino al adquiriente del original de la misma (Marco Molina, 1995, p. 22). Aunque la ley no se refería a la fotografía quizá sentaba un precedente que permitía usar libremente y sin acreditar los negativos adquiridos a terceros.

La colaboración parece animada por un «hambre de imágenes». El silencio documental no permite establecer hipótesis sobre estos préstamos, simétricos y bidireccionales, que los hace excepcionales en el contexto de la Expedición hasta donde sabemos. Pero sugiere, por ejemplo, que el fotógrafo conser- vaba, en efecto, sus derechos sobre las imágenes, lo que a su vez ayudaría a explicar su intensa colaboración con El Museo Universal. Por parte de Vischer, preocupado por los derechos de publicación como puede observarse en sus imágenes (registradas), el uso de los créditos no sólo expresa una colaboración honesta sino una búsqueda de autoridad y de prestigio para sus publicaciones.

Existen antecedentes en lo que se refiere a la reutilización de las imágenes producidas por las expediciones. Como indica Brian Bockelman, las vistas de Buenos Aires realizadas por Fernando Brambila en la Expedición Malaspina fueron utilizadas por José María Cardano para recrear la frustrada invasión británica de la ciudad americana y más tarde para formar parte del atlas de Voyage dans l'Amerique Meridionale, de Félix de Azara (París, Dentu, 1809). La difusión de la imagen por parte de Azara tuvo a su vez como consecuencia un nuevo préstamo y alteración del dibujo original de la Expedición. Y así se sucedieron varias versiones más o menos fieles hasta 1841 (Bockelman, 2012, pp. 7778). En el caso de la Expedición del Pacífico, la publicación por Vischer de una de las fotografías de las minas de Murphy's en Pictorial of California (San Francisco, 1870) facilitó su circulación en los Estados Unidos; la imagen sería nuevamente utilizada por el ecologista Francis P. Farquhar en su edición de las cartas de WiIliam H. Brewer, un claro homenaje a este naturalista y a la exploración norteamericana ${ }^{52}$. Si bien la fotografía de Castro pasa a ilustrar la narrativa de otra expedición contribuyendo así al homenaje que la más importante organización ecologista de California y el ámbito académico le ofrecieron a este científico norteamericano, sus créditos perpetuaron la memoria de la Expedición del Pacífico contribuyendo a lo largo del tiempo al prestigio ansiado por el gobierno español.

\section{LOS CHINOS DE CALIFORNIA}

Si bien las colecciones del Pacífico incluyen fotografías de tipos humanos (Puig-Samper, 1992), se sabe que el fotógrafo sentía un interés especial por otras culturas que, en general, describe con una sensibilidad ajena a las teorías racistas imperantes.

En California obtuvo tres retratos colectivos de emigrantes chinos, ACN000/008/133, ACN000/008/134 y ACN000/008/135 (imagen 6). Perdidas las identidades de los modelos que pasan a representar a los chinos de California, los retratos se convierten en fotografías de tipos humanos. Como tales, estas imágenes difieren enormemente de otras fotografías concebidas como tipos (figuras de pie contra fondo 
neutro o en diferentes actitudes y con objetos emblemáticos de su etnia y ocupación), representación cuya tradición es bien visible en obras del siglo anterior (Badia-Villaseca, 2007, pp. 60-61, Badia-Villaseca, 2008, pp. 100-101) y cuyos orígenes posiblemente se remontan hasta los primeros "trachtenbuch". Con todo, los retratos de chinos coinciden en su formulación con otras imágenes, concretamente las de la familia del cacique Huaramán de Emilio Chaigneau adquiridas por la Comisión en Valparaíso, lo que viene a demostrar que la fotografía de interés antropológico en la década de 1860 abarcaba un amplio espectro de estilos.
Al margen del espectáculo de ópera china, en su crónica Castro llama también la atención sobre las dificultades que encontró a la hora de fotografiar a sus modelos, lo que demuestra a su vez el enorme interés que sintió por realizar estos retratos ${ }^{53}$. Esta dificultad no difiere de la descrita en los contactos con la tecnología occidental de otros pueblos, posiblemente explotada por los agentes del imperialismo con fines propagandísticos dado que fue una reacción generalizada durante los primeros años de la fotografía. Sin embargo, la reutilización de retratos como fotografías de tipos humanos ha sido considerada un fenómeno frecuente en la fo-

Imagen 6. Rafael Castro y Ordóñez, [Retrato de Chinos]. 1863, negativo al colodión húmedo sobre placa de vidrio, 22,0 x 17,0 cm. CCSIC, Museo Nacional de Ciencias Naturales, Madrid. Sig. ACN000/008/135.

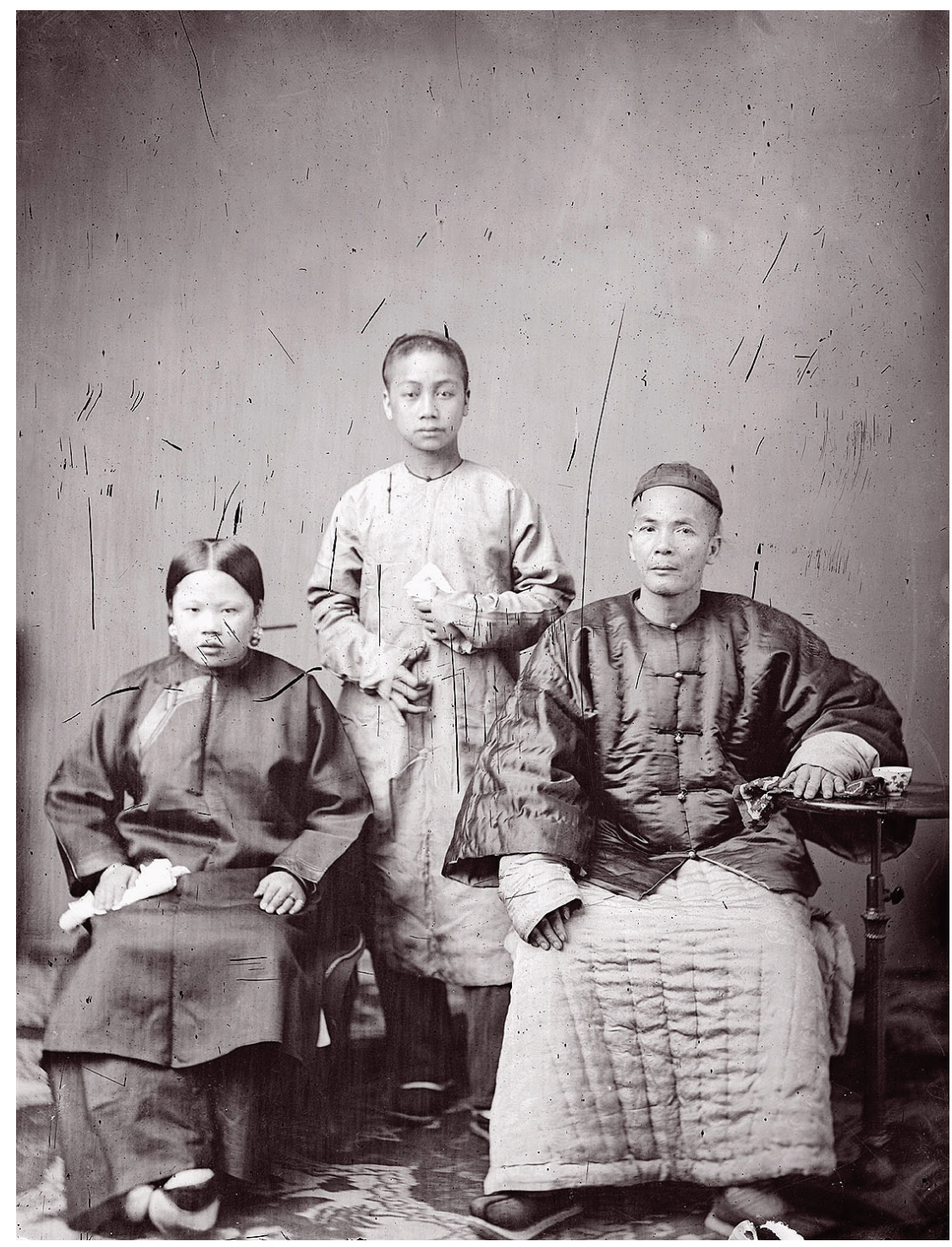


tografía de la China del siglo XIX (Thiriez, 1999, p. 102), y podría explicar en parte estas dificultades. Sin embargo, no cabe duda de que existe una clara relación entre estas fotografías y el retrato ancestral chino, que sirvió de inspiración a los primeros retratos fotográficos en China hasta que estos finalmente los sustituyeron. Diferentes testimonios de la época parecen apuntar a un "miedo al doble " $^{54}$ que derivaría del género del retrato ancestral chino ${ }^{55}$, cuya función era la de representar a los difuntos en el tradicional culto a los antepasados. Estos retratos, auténticos vehículos de contacto con los fallecidos, se inspiraban en las representaciones de las divinidades, y mostraban a los individuos inexpresivos, sedentes y en posición frontal. La mesa tradicional o de atrezo que acompaña a los modelos fotográficos podría proceder de ciertos tipos de retratos conmemorativos pero, especialmente, de la estética de los primeros daguerrotipos. Otras adaptaciones del retrato fotográfico a la estética pictórica china incluyen el rechazo de la perspectiva ${ }^{56}$, la omisión de la sombra y la representación completa de los objetos ${ }^{57}$.

Los retratos de Castro, particularmente ACN000/008/133 y ACN000/008/135, participan de estas convenciones, también comentadas por el fotógrafo John Thomson en $1872^{58}$. La imagen ACN000/008/134, próxima a la «conversation piece», demuestra mayor control por parte del artista pero, en general, el conjunto ilustra la difícil negociación entre fotógrafo y modelos y sugiere un control parcial por parte de estos sobre su propia representación. Las fotografías no aparecen representadas en todas las colecciones madrileñas, ni fueron publicadas por El Museo Universal, particularmente sensible a este tipo de imágenes.

Más importante aún, los motivos que animaron al fotógrafo a tomar estas imágenes fueron posiblemente el exotismo de los personajes, a los que denomina "diablitos de coleta ${ }^{59}$, pero también el hecho de que además permitían ilustrar el éxito del sistema norteamericano. Los chinos de California, si bien no eran bien considerados por sus conciudadanos, eran parte de una comunidad que el fotógrafo describe de la siguiente forma: "... Todas las nacionalidades tienen aquí cabida (...) todos se entienden... todos progresan y viven en armonía perfecta. Esa creencia de que pueblos constituidos bajo este sistema son el desorden cae por su base... $»^{60}$. Un gran elogio al proyecto nacional norteamericano.

\section{CONCLUSIONES}

Como producto de la Expedición del Pacífico, esta re-presentación fotográfica de América tras la independencia ante la sociedad española debe entenderse fundamentalmente como expresión de la ideología panhispanista que anima el proyecto. Sin embargo, el carácter apasionado de su autor, Rafael Castro y Ordóñez, permite observar múltiples aportaciones personales a lo largo del proyecto. Con todo, esta nueva iconografía americana debió gozar de crédito por su naturaleza tecnológica y por su relación con una comisión científica y militar, lo que la permitió circular ampliamente y tener una importante proyección.

Posiblemente influido por la mala marcha del proyecto y el fallecimiento de varios de sus componentes, el fotógrafo aportó una imagen personal de California. Esta ruptura del discurso oficial, que no debió de ser del agrado del gobierno ni de El Museo Universal, habla de un progreso americano imparable que le permite reflexionar sobre el declive de España. Como otros conocidos intelectuales y viajeros de la época, Castro utiliza su viaje para profundizar sobre la realidad española con vistas a una posible "regeneración». Con todo, su uso de los Estados Unidos como modelo parece excepcional en el contexto español.

Fotografías y crónicas del interior de California definen este Estado como un lugar en pleno proceso de desarrollo. La percepción del circuito de Calaveras en el bosque de secuoyas gigantes oscila entre la exhibición museística del espécimen botánico y la de la naturaleza domesticada y explotada con fines turísticos, expresión del imparable progreso norteamericano. Sorprendentemente no se observa por parte de los comisionados ninguna preocupación con relación a la supervivencia de estos árboles amenazados, de la que era consciente la opinión pública. En cuanto a las fotografías de las minas de la vecina localidad de Murphy's, también oscilan entre la imagen documental, de enorme éxito a juzgar por su amplia circulación, y quizá una cierta vocación moralizante.

Los préstamos visibles en la obra del comisionado y su colaborador local Edward Vischer sugieren una estrecha cooperación bidireccional y simétrica y parecen apoyar la tesis de que Castro conservaba entonces los derechos sobre sus placas. La utilización como base de partida y posterior perpetuación de la tradición creada en torno a este lugar turístico repleto de significado para la cultura norteamericana nos permite hablar de la participación del fotógrafo en una experiencia estandarizada muy similar a la del Grand Tour. Con todo, la 
repetición de imágenes procedentes de expediciones científicas, incluso a partir de su reproducción en otras obras, es un fenómeno visible en proyectos oficiales anteriores. En todos los casos se trata de «hambre de imágenes», que sin duda explica también el uso de las fotografías de Castro en suelo norteamericano. La autoridad que se les otorga a través de sus créditos contribuye a hacer de ellas fuentes fiables que merece la pena «citar». La fotografía de la mina de oro de Murphy's, reproducida con sus créditos en una edición de las cartas de uno de los miembros de la California Geological Survey, contribuyó no sólo a generar las imágenes que esta expedición requería sino a rendir homenaje al ilustre hombre de ciencia autor de esta narrativa. Pero la circulación de estas fotografías generó también algo de ese ansiado prestigio buscado por la Expedición del Pacífico. En cuanto al uso de imágenes de Vischer por parte del fotógrafo de la Comisión, no resulta excepcional en el contexto de la Expedición, que consta de un archivo paralelo de imágenes de origen local que en ocasiones fueron publicadas sin acreditación. Sin duda, un tema que merece un estudio más detallado.

Ajenas a los cánones de la representación de tipos, los retratos de chinos de California realizados por Cas-

\section{NOTAS}

1. "Chile", La Gazeta de Puerto Rico, 11 de agosto de 1863, 4, [en línea], disponible en: http://chroniclingamerica.loc. gov/lccn/2013201074/1863-08-11/ed-1/seq-4/ [consultado el 26/9/2016].

2. AMNM (Archivo del Museo Naval de Madrid). Manuscrito 2219, folio 5. Carta de Alejandro Malaspina a Antonio Valdés. 26 de diciembre de 1788. En: Sotos Serrano, Carmen (1982), Los pintores de la expedición de Alejandro Malaspina, Madrid, Real Academia de la Historia, p. 178.

3. Martínez y Sáez, Francisco de Paula (1994), Diario de don Francisco de Paula Martínez y Sáez, miembro de la Comisión Científica del Pacífico (1862-1865), María Ángeles Calatayud Arinero (ed.), Madrid, CSIC, p. 38.

4. Cook, James, The Three Voyages of Captain James Cook round the World, London, Longman, Hurst, Rees, Orme and Brown, 1821, vol.5. p. 93 [en línea], disponible en: https://books. google.es/books?id=h6UFAAAAMAAJ\&pg=PA85\&lpg=PA85 \&dq=The_Three_Voyages_of_+Captain+James+Cook.\&sour ce=bl\&ots=KORKvqehEd\&sig=K4H-DSviqC1aNiKBfmUkWKy8 ZXM\&hl=es\&sa=X\&ved=0ahUKEwjDm8Css63PAhXEExoKHe LCPCQ6AEIVDAH\#v=onepage \&q=The_Three_Voyages_of_\%20 Captain\%20James\%20Cook.\&f=false [consultado el 26/9/2016]

5. Almagro, Manuel (1866), Breve descripción de los viajes hechos en América por la Comisión Científica enviada por tro, con una clara influencia de la estética china, no cosecharon el éxito esperado por el fotógrafo, quien manifestó un gran interés por obtenerlos. Las imágenes, cuya función cambia del retrato al tipo humano, vienen a confirmar el carácter vacilante de las fotografías de interés antropológico en las primeros años de 1860. Por otra parte, la ruptura en el discurso demuestra no sólo cierto control por parte de los modelos sobre su representación, sino que confirma la existencia de este tipo de "retrato fotográfico chino» con relación a sus clientelas. Las imágenes de los chinos de California, quizá la población más exótica a ojos del fotógrafo, constituye además otro signo del éxito del sistema norteamericano.

Las imágenes de Rafael Castro son pioneras en la representación de estas tierras, entonces aún mal conocidas, y posiblemente debido a ello circularon en los Estados Unidos a través de los años proporcionando el prestigio ansiado por la Expedición. Por el contrario, una visión tan personal de los Estados Unidos, posiblemente contraria a los intereses de sus mecenas, quizá comprometió la carrera de Rafael Castro a su regreso a España y contribuyó a su suicidio, expresión romántica del artista incomprendido.

el gobierno de S. M. C. durante los años de 1862 á 1866, Madrid, Imprenta de M. Rivadeneira.

6. AMNCNM (Archivo del Museo Nacional de Ciencias Naturales de Madrid). Sig. ACN0041/730/061. Carta de José Aribau a Mariano de la Paz y Graells, 16 de septiembre de 1866.

7. AGA (Archivo General de la Administración Pública). Leg. 14717. Informe de Mariano de la Paz y Graells sobre la petición de Rafael Castro, 8 de marzo de 1865.

8. AGA. Leg. 14717. Real Orden, 8 de julio de 1865.

9. AGA. Leg. 6515. Informe sobre la realización de 20 álbumes por Sebastián Mudarra, Negociado 1ํ, 15 de marzo de 1866 a 2 de julio de 1868 .

10. AGA. Leg. 6515. Expediente de los 20 álbumes encargados a Sebastián y José Mudarra, 15 de marzo de 1866-1 de junio de 1868.

11. AMNCNM. Sig. ACN0042/764/016. Solicitud de ejemplares de los libros de la Expedición al Pacífico y una colección de fotografías, marzo de 1879.

12. Almagro, Manuel (1866), Breve descripción de los viajes hechos en América por la Comisión Científica enviada por el gobierno de S. M. C. durante los años de 1862 á 1866, Madrid, Imprenta de M. Rivadeneira. 
13. AMNCNM. Sig. ACN0041/730/086. Recibí de 130 escudos por 21 marcos grandes para colocar las vistas fotográficas, 2 de enero de 1867.

14. AGA. Leg. 14717. Patricio María Paz y Membiela, Indagación sobre los trabajos fotográficos de Rafael Castro y su sueldo, 14 de febrero de 1865; Rafael Castro y Ordóñez, Instancia por la privación de los derechos de propiedad sobre sus imágenes, 2 de agosto de 1865.

15. AHAM (Archivo Histórico Arzobispal de Madrid). Iglesia Parroquial de San Martín, leg. 67, bautizos 1o de marzo de 1833 a 31 ㅇ de diciembre de 1834. Luis Pérez, Partida de bautismo de Rafael Casto Castro y Ordóñez, [31 diciembre 1834].

16. AGA. Leg. 31, caja 6783. Antonio Castro y Gistán, Solicitud de una plaza de restaurador del Museo Nacional, 15 mayo 1861.

17. Hidalgo, Dionisio, Boletín Bibliográfico Español, [en línea], disponible en: https://archive.org/stream/boletnbibliogrf04piergoog/boletnbibliogrf04piergoog_djvu.txt

18. Hidalgo, Dionisio, Boletín Bibliográfico Español, [en línea], disponible en: https://archive.org/stream/boletnbibliogrf04piergoog/boletnbibliogrf04piergoog_djvu.txt

19. Anuncio de prensa, "Vistas de Estereóscopo, de todos [los] países," La Correspondencia de España, 5 de febrero de 1862, p. 4, [en línea], disponible en: http://prensahistorica. mcu.es/es/publicaciones/listar numeros.cmd?tipo busque $\mathrm{da}=$ calendario \&posicion=\&busq_infoArticulos=true $\&$ subm it=Buscar\&busq_dia=5\&busq_idPublicacion=8095\&busq mes=2\&busq_anyo=1862 [consultado el 26/9/2016]

20. Castro, R., "Expedición Científica al Pacífico. San Francisco de California, 27 de octubre de 1863", El Museo Universal, 31 de enero de 1864, pp. 36-37.

21. Castro y Ordóñez, Rafael, "Expedición Científica al Pacífico. A bordo de la fragata de guerra Triunfo en la mar a 1을 diciembre de 1863", El Museo Universal de 3 de abril de 1864, p. 109.

22. Castro, R., "Expedición Científica al Pacífico. A bordo de la fragata de guerra Triunfo en la mar a 1을 de diciembre de 1863", El Museo Universal de 3 de abril de 1864, pp. 109-110.

23. AMNM. Leg. 1412-000. Carta del guardiamarina Joaquín Bustamante a su madre, 17 de noviembre de 1863.

24. Castro y Ordóñez, Rafael, "Expedición Científica al Pacífico. San Francisco de California, 27 de octubre de 1863", El Museo Universal, 31 de enero de 1864, pp. 36-37.

25. Castro y Ordóñez, Rafael, "Expedición Científica al Pacífico. San Francisco de California, 29 de octubre de 1863", El Museo Universal, 14 de febrero de 1864, p. 54.

26. Castro, R., “Expedición Científica al Pacífico. San Francisco de California, 27 de octubre de 1863", El Museo Universal, 31 de enero de 1864 , p. 35
27. Castro, R., "Expedición Científica al Pacífico. San Francisco de California, 27 de octubre de 1863", El Museo Universal, 31 de enero de 1864, pp. 35-36.

28. Castro, R., "Expedición Científica al Pacífico. San Francisco de California, 29 de octubre de 1863", El Museo Universal, 14 de febrero de 1864, p. 54.

29. Castro, R., "Expedición Científica al Pacífico. San Francisco de California, 27 de octubre de 1863", El Museo Universal, 31 de enero de 1864 , p. 36.

30. “Chile," La Gazeta de Puerto Rico de 11 de agosto de 1863, 4.

31. Castro, R., "Expedición Científica al Pacífico. San Francisco de California, 29 de octubre de 1863", El Museo Universal, 14 de febrero de 1864, p. 52

32. Vischer, Edward (1862), Views of California: The Mammoth Tree Grove, Calaveras County, California, and its Avenues, San Francisco, [en línea], doi: 10.5962/bhl.title.50746

33. AMNM. Sig. ACN0038/689/002. Francisco de Paula Martínez y Sáez, Diario, 1862-1866.

34. Se toma como referencia la signatura de los negativos de la colección del Museo Nacional de Ciencias Naturales. Las fotografías pueden consultarse on-line en "Archivos: Documentación textual e iconográfica" de la red de bibliotecas del CSIC, http://bibliotecas.csic.es/catalogos.

35. Honnold Mudd Library, Special Collections. Vischer, Edward (después de 1863), Vischer's Views of California, the Mammoth Tree Grove, Calaveras County, California and its Avenues, San Francisco, Impresión del autor, [en línea], disponible en: http://ccdl.libraries.claremont.edu/cdm/compoundobject/collection/vdp/id/336/rec/3 [consultado el 15/1/2016].

36. Yale Collection of Western Americana, Beinecke Rare Book and Manuscript Library. Sig. Zc72+864x. Sr Martínez de Castro [Castro y Ordóñez, Rafael], The Upper Portion of the Original Big Tree and Surrounding Debris ... by Señor Martínez de Castro, phot of the Scientific Commission of Spain. 1863 , reproducción en papel albuminado de una copia en papel albuminado. Edward Vischer (1864), The Forest Trees of California, San Francisco.

37. Farquhar, Francis P. (ed) (1930), The Journal of William H. Brewer, Professor of Agriculture in the Sheffield Scientific School from 1864 to 1903, New Haven, Yale University Press; London: Humphrey Milford, Oxford Univeristy Press, pp. 397-399.

38. Farquhar (1930), p. 398 y Castro y Ordóñez, R., “Expedición Científica al Pacífico. San Francisco de California, 29 de octubre de 1863", El Museo Universal, 14 de febrero de 1864, p. 53.

39. Castro, R., "Expedición Científica al Pacífico. San Francisco de California, 29 de octubre de 1863", El Museo Universal, 14 de febrero de 1864, p. 53. 
40. Castro, R., "Expedición Científica al Pacífico. A bordo de la fragata de guerra Triunfo en la mar a 10 de diciembre de 1863", El Museo Universal de 3 de abril de 1864, pp. 109-110.

41. Ruiz, [Federico] (dibujo), Pisón (grabado), Expedición al Pacífico.- Árboles gigantes, La Madre y el Hijo; [Federico] Ruiz (dibujo), [llegible], Expedición al Pacífico-Árboles Gigantes, grupo de las Tres Gracias, El Museo Universal, 3 de abril de 1864, p. 108 [en línea], disponible en: http://www.cervantesvirtual.com/ obra/el-museo-universal--315/ [consultado el 27/1/2016].

42. "La California y sus maravillas," El Museo Universal, 22 de noviembre de 1863 , p. 372, [en línea], disponible en: http:// www.cervantesvirtual.com/obra/el-museo-universal--306/ [consultado el 18 de enero de 2016]

43. "An Immense Tree," Gleason's Pictorial Drawing Room Companion, 1 octubre 1853, p. 217, [en línea], disponible en: https://archive.org/details/gleasonspictoria0506glea [consultado el 26/9/2016]

44. "La California y sus maravillas," El Museo Universal, 22 de noviembre de 1863, p. 372.

45. Almagro, Manuel (1866), Breve descripción de los viajes hechos en América por la Comisión Científica enviada por el gobierno de S. M. C. durante los años de 1862 á 1866, Madrid, Imprenta de M. Rivadeneira, p. 71.

46. Honnold Mudd Library, Special Collections. Vischer, Edward (1870), Pictorial of California, San Francisco, p. 2, [en línea], disponible en: http://ccdl.libraries.claremont.edu/cdm/ ref/collection/vdp/id/1332 [consultado el 29/1/2016].

47. [Federico] Ruiz (dibujo), Rafael Castro y Ordóñez (fotografía), Expedición Científica al Pacífico, California-Lavadero de oro, Ilano de Murphys. 1863-1864, grabado en madera como ilustración de texto. El Museo Universal, 27 de marzo de 1864, p. 100, [en línea], disponible en: http://www.cervantesvirtual.com/ obra/el-museo-universal--136/ [consultado el 27/1/2016].

48. Bancroft Library, University of California, Sig. f F866 .V83 1870. [Castro y Ordóñez, Rafael], Mining Scene near Murphy's, Vischer (1870), [p. 152] y [Castro y Ordóñez, Rafael], Hydraulic Mining, from a photograph by Don Rafael Ordóñez Castro, of the Pacific Squadron of Spain, 1863, Farquhar (1930), p. 350.

\section{BIBLIOGRAFÍA}

Badia-Villaseca, Sara; López-Ocón, Leoncio y Pérez-Montes Carmen María (2000), “Una galería iconográfica”. En: LópezOcón, Leoncio, Pérez-Montes, Carmen María (eds.), Marcos Jiménez de la Espada (1831-1898). Tras la senda de un explorador, Madrid, CSIC, pp. 121-154.

Badia-Villaseca, Sara (2007), "Las fotografías de Rafael Castro y Ordóñez". En: Sagredo Baeza, Rafael, Puig-Samper, Miguel Ángel (eds.), Imágenes de la Comisión Científica del Pacífico en Chile, Santiago de Chile, Editorial Universitaria, S. A., pp. 41-81.
49. Castro, R., "Expedición Científica al Pacífico. San Francisco de California, 29 de octubre de 1863", El Museo Universal, 14 de febrero de 1864, p. 54.

50. Vischer, Edward (1862), Views of California: The Mammoth Tree Grove, Calaveras County, California, and its Avenues, San Francisco, [p. III] [en línea], doi: http://dx.doi. org/10.5962/bhl.title.50746.

51. Castro, R., "Expedición Científica al Pacífico. San Francisco de California, 27 de octubre de 1863", El Museo Universal, 31 de enero de 1864 , p. 35.

52. [Rafael Castro y Ordóñez], Hydraulic Mining, From a photograph by Don Rafael Ordóñez Castro, of the Pacific Squadron of Spain, 1863. [1863], reproducción. Farquhar (1930), p. 350.

53. Castro, R., "Expedición Científica al Pacífico. A bordo de la fragata de guerra Triunfo en la mar a 10 de diciembre de 1863", El Museo Universal de 3 de abril de 1864, p. 110.

54. Griffith, D. K.,'A Celestial Studio”, The Photographic News, 28 mayo de 1875 , pp. 259-261.

55. Thomson, John (1982), "Introduction." En: China and Its People in Early Photographs; An Unabridged Reprint of the Classic 1873/4 Work, New York: Dover Publications Incorporated, [s. p.]

56. "Photography in Eastern Asia", The Photographic News, 29 de febrero de 1884, [s. p.].

57. Thomson, J., "Hong Kong Photographers", The British Journal of Photography, 13 de diciembre de 1872, p. 569.

58. Thomson, John, "Hong Kong Photographers", The British Journal of Photography, 13 de diciembre de 1872, pp. 569, 591.

59. Castro, R., "Expedición Científica al Pacífico. A bordo de la fragata de guerra Triunfo en la mar a 1을 de diciembre de 1863", El Museo Universal de 3 de abril de 1864, p. 110.

60. Castro, R., "Expedición Científica al Pacífico. San Francisco de California, 27 de octubre de 1863", El Museo Universal, 31 de enero de 1864, p. 36

Badia-Villaseca, Sara (2008), "A obra de Rafael Castro y Ordóñez, fotógrafo da Comissão Científica do Pacífico (18631865)", Revista Porto Arte, 15 (25), pp. 92-103.

Barreiro, P. Agustín Jesús (1926), Historia de la Comisión Científica del Pacífico (1862-a 1865), Madrid, Museo Nacional de Ciencias Naturales.

Blanco Fernández de Caleya, Paloma; Rodríguez Veiga Isern, Dolores y Rodríguez Veiga Isern, Pilar (2006), El estudiante de las hierbas. Diario del botánico Juan Isern Batlló y Carrera 
(1821-1866), miembro de la Expedición Científica del Pacífico (1862-1866), Madrid, CSIC.

Bockelman, Brian (2012), "Along the Waterfront. Alejandro Malaspina, Fernando Brambila, and the Invention of the Buenos Aires Cityscape, 1789-1809", Journal of Latin American Geography, 11, pp. 61-88, [en línea], doi: 10.1353/ lag.2012.0024

Boneu Farre, Eusebio J. (1962), "Castelar y la fórmula del progreso", Revista de Estudios Políticos, (124), pp. 99-132.

Burdiel, Isabel (2011), Isabel II. Una biografía (1830-1904), Madrid, Taurus.

Cikovski, Nicolai (Jr) (1979), "'The Ravages of the Axe'. The Meaning of the Tree Stump in Ninteenth-Century American Art", The Art Bulletin, 61 (4), pp. 611-626, [en línea], doi: 10.1080/00043079.1979.10787708

Chozas Ruiz-Belloso, Diego (2014), "La literatura de viajes en EI Museo Universal, (1857-1869)", Tesis doctoral, Zaragoza, UZ, pp. 106, 109, [en línea], disponible en: https://zaguan.unizar.es/record/15781/files/TESIS-2014-075.pdf [consultado el $4 / 2 / 2016]$

Díaz Larios, Luis Federico (2002), "La visión romántica de los viajeros románticos". En Actas del VIII Congreso sobre Romanticismo "Los románticos teorizan sobre sí mismos", BoIonia, pp. 87-100.

Donko, Wilhelm (2011), An Austrian View of the Philippines, Berlin, Verlagsgruppe Holtzbrinck.

Fernández de Miguel, Daniel (2012), El enemigo yanqui: las raíces conservadoras del antiamericanismo español, Zaragoza, Genueve Ediciones.

Fontanella, Lee (1981), Historia de la fotografía en España, desde sus orígenes hasta 1900, Madrid, El Viso.

Hutchinson, Elizabeth (2004), "They Might Be Giants. Carleton Watkins, Galen Clark, and the Big Tree", October, (109), pp. 4763, pp. 54, 57, [en línea], doi: 10.1162/0162287041886476

Inarejos Muñoz, Juan Antonio (2007), Intervencionales coloniales y nacionalismo español. La política exterior de la Unión Liberal y sus vínculos con la Francia de Napoleón III (18561868), Madrid, Sílex.

Khan, Zorina (2008), "Copyright Piracy and Development: United States Evidence in the Nineteenth Century", Revista de Economía Institucional, 1, pp. 21-54.

López-Ocón, Leoncio y Badia-Villaseca, Sara (2003), “Overcoming Obstacles. The Triple Mobilization of the Comisión Cientifica del Pacífico", Science in Context 16 (4), pp. 505-534.

Marco Molina, Juana (1995), La propiedad intelectual en la legislación española, Madrid, Marcial Pons.
Martínez Gallego, Francesc A. (2001), Conservar progresando. La Unión Liberal (1856-1868), Valencia, Centro Francisco Tomás y Valiente UNED Alzira-Valencia.

Miller, Robert Ryal (1968), For Science and National Glory. The Spanish Scientific Expedition to America, Norman, University of Oklahoma Press.

Novak, Barbara (1980), Nature and Culture. American Landscape and Painting, 1825-1875, New York, Oxford, Oxford University Press.

Ossorio y Bernard, Manuel (1868), Galería biográfica de artistas españoles del siglo XIX, Madrid, Imprenta de Ramón Moreno.

Palmquist, Peter E. (1982), “Don Rafael's Tree”, History of Photography, 6 (1), pp. 15-19, [en línea], doi: 10.1080/03087298.1982.10442702

Pantorba, Bernardino de (1980), Historia y crítica de las exposiciones nacionales de Bellas Artes celebradas en España, Madrid, Jesús Ramón García-Rama.

Patin, Thomas (1999), "Exhibitions and Empire. National Parks and the Performance of Manifest Destiny", Journal of American Culture, 22 (1), pp. 41-59, p. 41, [en línea], doi. 10.1111/j.1542-734X.1999.00041.x

Páez Ríos, Elena (1952), El Museo Universal, Madrid, (18571869), Madrid, CSIC.

Pérez Viejo, Tomás (2012a), “España en el mundo”. En: Burdiel, Isabel (coord), España, 1830-1880. La construcción nacional, tomo II, Madrid, Fundación MAPFRE y Santillana Ediciones Generales S. L., pp. 119-193.

Pérez Viejo, Tomás (2012b), “Géneros, mercado, artistas y críticos en la pintura española del siglo XIX," Espacio, tiempo y Forma, Serie V, Historia Contemporanea, 24, pp. 25-48.

Puig-Samper, Miguel Ángel y López-Ocón, Leoncio (1987), “Los condicionantes políticos de la Comisión Científica del Pacífico. Nacionalismo e hispanoamericanismo en la España bajoisabelina (1854-1868)", Revista de Indias XLVII (180), pp. 667-682.

Puig-Samper, Miguel Ángel (1988), Crónica de una expedición romántica al Nuevo Mundo, Madrid, CSIC.

Puig-Samper, Miguel Ángel (1991), "Románticos y nacionalistas. La Comisión Científica del Pacífico". En: Díez Torre, Alejandro R., Mallo T., et al (eds), La ciencia española de ultramar, Aranjuez, Doce Calles, pp. 335-346

Puig-Samper, Miguel Ángel (1992), Pacífico Inédito (1862-1866). Exposición fotográfica, Barcelona, Lunwerg.

Puig-Samper, Miguel Ángel (2011), California a través de la lente de una expedición romántica, Madrid, $\mathrm{BOE}, \mathrm{pp} .28,38$ 
Sánchez García, Raquel (2002), "La propiedad intelectual en la España contemporánea, 1847-1936," Hispania, 62 (212), pp. 993-1019.

Sears, John F. (1989), Sacred Places. American Tourist Attractions in the Nineteenth Century, New York, Oxford University Press.

Sweet, Rosemary (2012), Cities and the Grand Tour. The British in Italy, c. 1690-1820, Cambridge, Cambridge University Press.

Thiriez, Régine (1999), "Photography and Portraiture in Nineteenth-Century China", East Asian History, 17/18, pp. 75-102.
Van Aken, Mark J. (1959), Panhispanism. Its Origin and Development to 1866, Berkeley, Los Angeles, University of California Press.

Vermaas, Lori (2003), Sequoia. The Heralded Tree in American Art and Culture [Washington D.C], Smithsonian Institution.

Yeves Andrés, Juan Antonio (2011), "Catálogo". En: Yeves Andrés, Juan Antonio (ed), Una imagen para la memoria, la "carte de visite": Colección de Pedro Antonio de Alarcón, Madrid, Fundación Lázaro Galdiano. 